\title{
Tree Response to Experimental Watershed Acidification
}

\author{
N. K. Jensen • E. J. Holzmueller • P. J. Edwards • \\ M. Thomas-Van Gundy • D. R. DeWalle • \\ K. W. J. Williard
}

Received: 6 March 2014 / Accepted: 13 June 2014 / Published online: 29 June 2014

(C) Springer International Publishing Switzerland (outside the USA) 2014

\begin{abstract}
Forest ecosystems in the Eastern USA are threatened by acid deposition rates that have increased dramatically since industrialization. We utilized two watersheds at the Fernow Experimental Forest in West Virginia to examine long-term effects of acidification on ecological processes. One watershed has been treated with ammonium sulfate (approximately twice the ambient deposition rate) since 1989 to simulate elevated acidic deposition, while the other served as a control. Prior to treatment, both watersheds were similar in age and species composition. Ten dominant overstory Prunus serotina and Liriodendron tulipifera trees were selected and cored from each watershed to measure bolewood concentrations of essential elements through time. In addition, changes in tree species basal area were analyzed utilizing 50 long-term growth plots. Results of this experiment show lower calcium and magnesium concentration and increased acidic cation concentration for both species in the treated watershed, indicating a negative treatment effect. Growth response, measured
\end{abstract}

N. K. Jensen • E. J. Holzmueller $(\bowtie) \cdot$ K. W. J. Williard Department of Forestry, Southern Illinois University, Carbondale 62901-4619 IL, USA

e-mail: eholzmue@siu.edu

P. J. Edwards • M. T.-. Gundy

USDA Forest Service, Northeastern Research Station,

Parsons, WV, USA

D. R. DeWalle

Department of Ecosystem Science and Management, The Pennsylvania State University,

University Park, PA, USA through relative growth rates of cored trees and changes in basal area from growth plots, was not as conclusive and appeared to differ by species. The resulting difference in species response indicates that acidification sensitivity is something that land managers should consider when managing forests affected by acidification.

Keywords Acid deposition - Black cherry - Fernow Experimental Forest $\cdot$ Hardwood $\cdot$ Liriodendron tulipifera $\cdot$ Prunus serotina $\cdot$ Yellow poplar

\section{Introduction}

Long-term productivity of mixed-species forest in the central Appalachian region of the USA is threatened by base cation depletion in the soil (Schuler 2004; Elias et al. 2009). Base cation depletion is often a result of acidification due to acid deposition or over-fertilization. These changes in soil nutrients can affect the nutrient uptake and growth of trees and, in extreme cases, can result in tree dieback (Driscoll et al. 2001; Sharpe 2002). The loss of economically important hardwood tree species raises concerns for the long-term future these forests (Adams et al. 2006).

Increased acidification observed in the Eastern USA can be traced to nitrogen and sulfur emissions from fossil fuel burning, in the form of wet and dry atmospheric depositions (Driscoll et al. 2001). Historically, northern temperate forests were nitrogen-limited systems. However, under chronic high-nitrogen deposition rates, nitrogen inputs can exceed the retention capacity 
of forest ecosystem and nitrogen saturation results (Agren and Bosatta 1988; Aber et al. 1989). These saturated conditions are characterized by increased levels of nitrogen export from forested watersheds (Stoddard 1994).

Although it is a nonessential element for living organisms, aluminum (Al) also plays an important role in the acidification of these forests. In acidic soils, Al solubility is controlled by $\mathrm{pH}$. As the soil $\mathrm{pH}$ drops below 5.5, $\mathrm{Al}$ begins to dissolve aluminosilicate clays and soil minerals, and as a result, $\mathrm{Al}$ and other metals (e.g., $\mathrm{Mn}, \mathrm{Fe}$, and $\mathrm{Cd}$ ) are released. Aluminum is most ubiquitous because it is building block of soil. Dissolved $\mathrm{Al}$ and other metals are exchanged for base cations (primarily $\mathrm{Ca}^{2+}, \mathrm{Mg}^{2+}$, and $\mathrm{K}^{+}$) on soil cation exchange sites, and as a result, base cation concentrations increase. This phase is termed cation mobilization. Through time as water drains through the soil profile, the base cations made available through the exchange are leached from the soil. Cation leaching is accelerated by high levels of nitrate and sulfate deposition associated with acidic deposition. This is because leaching requires that molecules travel as electrically neutral pairs, and nitrate and sulfate are readily available due to deposition inputs. Consequently, base cation supplies can become depleted by elevated exchange and leaching losses (depletion phases) in soils that have limited base cations and overlay base-poor geologic layers. As depletion occurs, Al and other metals replace base cations in solution, and in turn, the metals become leached at accelerated rates.

Depletion of base cations results in decreased soil fertility directly through the loss of nutrients and indirectly through biogeochemically induced changes to mineralization and nutrient cycling. As a result of these changes in soil chemistry forest health, species composition and growth may be effected (Edwards et al. 2002; DeForest and McCarthy 2011; Talhelm et al. 2013; Lu et al. 2013). However, due to the relatively short period ( $<50$ years), these changes have been under investigation, and the long-term effects of acidification are not fully understood.

To provide new insight into the forest acidification process, this study analyzed hardwood tree-ring chemistry and growth response data 22 years after experimental acidification began on a watershed in the Eastern USA (Adams et al. 2006). While previous studies have examined tree-chemistry response and growth rates in smaller trees (DeWalle et al. 2006), this study is the first to examine trees of commercial size $(>45 \mathrm{~cm})$. Tree-ring (dendrochemistry) chemistry provides a unique insight into this problem by allowing an examination of essential element concentrations over time, which serve as indicators of growth response. Since the early 1970s, tree-ring techniques have been used to monitor changes in soil and atmospheric chemistry as a form of environmental monitoring, and this method can result in a comprehensive look at changes over a given period of time (Watmough 1997). There are some limitations of tree-ring chemistry including the potential of radial translocation of elements, and individual tree species may respond differently to treatment (Watmough 1997; Beauregard et al. 2009); however, DeWalle et al. (1999) reported that overall, tree-ring chemistry appears to be a reliable indicator of tree nutrient status, as results generally agree with response to acidification treatments reported by others in areas of streamflow and soil data. For this study, we concentrated on two of the most common and ecologically important commercial hardwood tree species in the Eastern USA, Liriodendron tulipifera L. (yellow poplar) and Prunus serotina Ehrh. (black cherry). The results of this study may help improve management practices in areas susceptible to acidification.

\section{Materials and Methods}

\subsection{Experimental Site}

In 1989, an acidification study began on two watersheds within the Fernow Experimental Forest to evaluate the impacts of acid deposition on multiple ecosystem processes (Adams et al. 2006). The Fernow is located in the Allegheny Mountain region of North Central West Virginia. Established in 1934, it contains 1,902 ha consisting primarily of hardwood forest. It is part of the US Forest Service land base and is administered by the agency's Northern Research Station. Mean annual precipitation in the Fernow is $1.48 \mathrm{~m}$. The growing season extends 145 days, from May to October, with mean monthly temperatures ranging from $-18{ }^{\circ} \mathrm{C}$ (January) to $21^{\circ} \mathrm{C}$ (July).

One study watershed was used as a treated watershed. It is 34-ha and south-facing, with an average elevation of $800 \mathrm{~m}$. The overstory is dominated by $P$. serotina and L. tulipifera (Table 1), while the understory primarily consists of Acer rubrum L. (red maple), P. serotina, Quercus palustris Munchh. (pin oak), 
Table 1 Density (mean \pm 1 SE) of overstory tree species (DBH $\geq$ $30.5 \mathrm{~cm}$ ) in stems per hectare on the treated and control watersheds

\begin{tabular}{lll}
\hline Tree species & Treated watershed & Control watershed \\
\hline Betula lenta & - & $1.2 \pm 0.7$ \\
Quercus rubra & $4.4 \pm 2.1$ & $1.2 \pm 0.9$ \\
Liriodendron tulipifera & $10.0 \pm 2.6$ & $21.6 \pm 3.6$ \\
Prunus serotina & $52.0 \pm 6.0$ & $17.2 \pm 2.8$ \\
Robinia pseudoacacia & - & $4.8 \pm 2.1$ \\
Acer rubrum & $1.2 \pm 0.7$ & $1.2 \pm 0.9$ \\
Quercus prinus & $0.4 \pm 0.4$ & - \\
Total & $67.6 \pm 11.8$ & $47.2 \pm 11$ \\
\hline
\end{tabular}

Quercus rubra L. (Northern red oak), and Betula lenta L. (black birch) (Table 2). Common soils are Calvin channery silt loam (loamy-skeletal, mixed, active, mesic Typic Dystrochrept) (Kochenderfer 2006). This watershed was lightly and selectively harvested in 1959 and 1963 , followed by a patch cut and a clear-cut with herbicide treatments from 1968 to1972.

Beginning in 1989, and continuing to present time, the treated watershed has been fertilized (i.e., the treatment) with ammonium sulfate $\left((\mathrm{NH} 4)_{2} \mathrm{SO}_{4}\right)$ three times annually in the spring, summer, and autumn to simulate and accelerate watershed acidification. Spring and autumn application rates are $34 \mathrm{~kg}$ of fertilizer per hectare, approximately double the bulk $\mathrm{N}$ and $\mathrm{S}$ deposition rates estimated from through fall concentrations for January

Table 2 Density (mean \pm 1 S.E.) of understory tree species $(\mathrm{DBH}<30.5 \mathrm{~cm})$ in stems per hectare on the treated and control watersheds.

\begin{tabular}{lll}
\hline Tree species & Treated watershed & Control watershed \\
\hline Betula lenta & $7.2 \pm 2.1$ & $24.8 \pm 8.8$ \\
Quercus rubra & $8.0 \pm 3.5$ & $0.4 \pm 0.4$ \\
Magnolia acuminata & $1.2 \pm 0.9$ & - \\
Magnolia fraseri & $4.0 \pm 2.0$ & $0.8 \pm 0.6$ \\
Liriodendron tulipifera & $4.4 \pm 1.3$ & $7.2 \pm 3.3$ \\
Sassafras albidum & $1.2 \pm 0.9$ & - \\
Quercus palustris & $6.0 \pm 4.2$ & - \\
Prunus serotina & $30.8 \pm 5.2$ & $3.6 \pm 1.4$ \\
Robinia pseudoacacia & $1.2 \pm 0.9$ & $3.2 \pm 1.3$ \\
Acer saccharum & $0.4 \pm 0.4$ & $1.2 \pm 0.7$ \\
Acer rubrum & $8.0 \pm 2.4$ & $3.6 \pm 1.5$ \\
Fraxinus americana & $0 \pm 0.0$ & $1.6 \pm 1.2$ \\
Total & $72.4 \pm 23.8$ & $46.4 \pm 19.2$ \\
\hline
\end{tabular}

to April and September to December, while the summer application rates were $101 \mathrm{~kg}$ of fertilizer per hectare, approximately double the $\mathrm{N}$ and $\mathrm{S}$ bulk deposition rates between May and August (Adams et al. 2007).

A second, 24-ha control watershed is east-facing and adjacent to the treated watershed. It also has an average elevation of $800 \mathrm{~m}$. Similar to the treated watershed, the overstory is dominated by $L$. tulipifera and P. serotina (Table 1). The understory differs slightly and is dominated by B. lenta and L. tulipifera (Table 2). The dominant soil series is also Calvin channery silt loam. The control watershed was clear-cut from 1963 to 1967 and maintained barren with herbicides following cutting until 1969 when natural regrowth was allowed.

Prior to acidification treatment in 1989, vegetation differed slightly among the two watersheds, which may be attributed to earlier vegetation treatments (DeWalle et al. 2006). The treated watershed had a greater component of $P$. serotina and A. rubrum compared to the control while the control had a greater component of L. tulipifera and B. lenta (Adams et al. 2007). During the course of the experiment, however, early successional species decreased in importance in both watersheds, while L. tulipifera and P. Serotina increased in importance in both watersheds.

\subsection{Tree Cores}

To analyze the changes in cation availability within the treated and control watersheds, we examined the wood chemistry of $P$. serotina and L. tulipifera. These same species were examined previously on these same watersheds by DeWalle et al. (2006), so using them for this study provides a means for examining responses over a longer time period. These species were selected for their availability on both watersheds, lower probability of radial translocation, and dominant/codominant positions in the crown.

Following methodology of DeWalle et al. (2006), ten dominant overstory trees of each species were selected on each of the two watersheds in July 2011. Four cores were taken to the pith at diameter breast height (DBH) from upslope, downslope, and both contour directions using a 4-mm-diameter increment borer. After extraction, the cores were handled with latex gloves and rinsed with deionized water to avoid contamination. They were placed on ice in the field and then frozen in the laboratory until analysis. Increment borers were rinsed with deionized water in between samples to avoid 
contamination within and among trees. The DBH and bark thickness were measured using diameter tape and bark gauges, respectively, for each tree in all four directions.

Preparation for analysis of three of the four cores of each tree included separating the rings of cores manually with a razor blade into seven multiple year age groups ( 8 and 4 years prior to treatment and $4,8,12,16$, and 22 years after treatment) to examine chemical composition through time. Wood was composited by age group for each individual tree to obtain the required $0.5 \mathrm{~g}$ of wood for chemical analysis. Each section was also measured for length and weighed. The core segments were then dried for $48 \mathrm{~h}$ at $55^{\circ} \mathrm{C}$.

The tree samples were then sent to the Penn State Agriculture Analytical Services Laboratory to be analyzed for tree-ring element concentrations of Calcium (Ca), Magnesium (Mg), Manganese (Mn), and Al using inductively coupled plasma (ICP) emission spectroscopy (DeWalle et al. 2006). Samples were ground using a Wiley mill with a $2-\mathrm{mm}$ screen to a $0.5-1-\mathrm{mm}$ particle size. Next, 250-mg samples were weighed out and placed into a HotBlock ${ }^{\mathrm{TM}}$ from Environmental Express for digestion. Five milliliters of $\mathrm{HNO}_{3}$ was injected into each sample, and the temperature was slowly increased to $75{ }^{\circ} \mathrm{C}$ before injecting $3 \mathrm{ml}$ of $30 \% \mathrm{H}_{2} \mathrm{O}_{2}$. The temperature then was slowly increased to $110^{\circ} \mathrm{C}$ and maintained for $30 \mathrm{~min}$ before cooling. Once the samples cooled, they were brought up to $50-\mathrm{ml}$ volume and inverted three times to mix the contents thoroughly. Each sample then was analyzed on the ICP-AES (Huang and Shulte 1985).

The fourth core was mounted, sanded, and scanned into WinDendro ${ }^{\text {TM }} 2009$ b, c. Although both species are diffuse porous species, rings were marked with the program and manually adjusted to age the tree and check measurements taken from the other three cores of the tree. Measurements from WinDendro ${ }^{\mathrm{TM}} 2009 \mathrm{~b}$, c were used to calculate relative radial growth.

\subsection{Growth Plots}

Field inventories were conducted in 1990, 1996, 1999, 2003, and 2009 by US Forest Service personnel using 25 0.04-ha permanent growth plots on the treated watershed. The same inventories were made on the control watershed except that they began in 1991. Diameter and species were recorded for all overstory $(\geq 30.5 \mathrm{~cm})$ and understory $(<30.5 \mathrm{~cm})$ trees taller than $1 \mathrm{~m}$. These measurements were used to determine basal area and stand density in both watersheds for all species, as well as for P. serotina and L. tulipifera separately.

\section{Statistical Analysis}

To maximize the value of the current data, many of the analyses were performed using the same approaches in the earlier papers from these same watersheds by DeWalle et al. (1999, 2006). Tree-chemistry data from the cores were analyzed using $t$ tests to determine differences between element concentrations of $\mathrm{Ca}, \mathrm{Mg}$, $\mathrm{Mn}$, and $\mathrm{Ca} / \mathrm{Mn}$ molar ratio in the treated areas and control areas for each tree species by age group (DeWalle et al. 2006). DeWalle et al. (1999) proposed $\mathrm{Ca} / \mathrm{Mn}$ molar ratio as an indicator of the effects of atmospheric deposition on soil acidification. Data from the scanned cores also were analyzed to calculate the relative radial growth, where relative radial growth= annual radial increment $(\mathrm{mm})$ for a year after treatment/mean annual radial increment $(\mathrm{mm})$ in that tree over 14 years before treatment (DeWalle et al. 2006). Growth plot data were used to find the average density for each watershed. Basal area for all species on each watershed was calculated and for P. serotina and L. tulipifera individually. These measurements were used to calculate the change in basal area over time $\left(\mathrm{m}^{2} \mathrm{ha}^{-1} \mathrm{yr}^{-1}\right) . t$ Tests were used to determine differences between watersheds for change in basal area for total basal area as well as P. serotina and L. tulipifera basal area.

\section{Results}

\subsection{Dendrochemistry}

P. serotina showed similar trends in $\mathrm{Ca}$ and $\mathrm{Mg}$ concentrations in bolewood in treated and control watersheds with a slight decrease from 1981 to 1996 and then increasing to present day(Figs. 1a and 2a). Slightly greater concentrations were observed for $\mathrm{Ca}$ in the control watershed compared to the treated watershed after 1996 ( $p \leq 0.09$ ), but no clear differences were observed in $\mathrm{Mg}$ concentrations. Manganese concentrations, however, were greater in the treated watershed $(p \leq 0.05)$, and this difference appeared to widen over time (Fig. 3a). Resulting $\mathrm{Ca} / \mathrm{Mn}$ molar ratios show a significant 

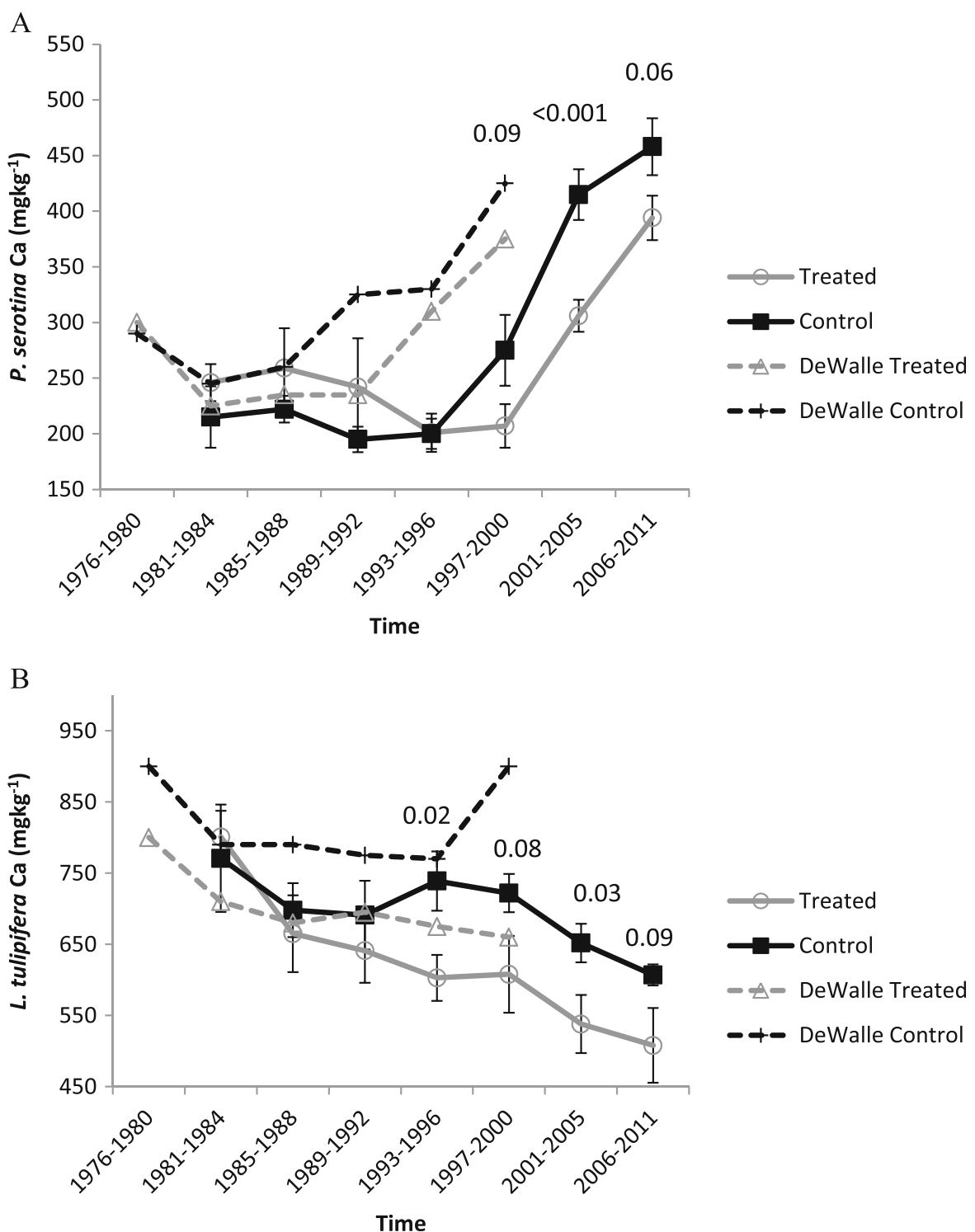

Fig. 1 P. serotina (a) and L. tulipifera (b) bolewood calcium concentrations (mean $\pm 1 \mathrm{SE}$ ) on treated and control watersheds after 22 years of treatment and previous findings from DeWalle et al. (2006). Treatment began in 1989. $P$ values depict differences between treatments for a given time period

0.08; Fig. 3b), and beginning in 1993, $\mathrm{Ca} / \mathrm{Mn}$ ratios were greater in the control watershed as was also observed with $P$. serotina ( $p \leq 0.07$; Fig. $4 \mathrm{~b})$.

\subsection{Tree Growth}

Scanned cores that were used to calculate the relative radial growth for each species on treated and controlled watersheds revealed an overall decreasing growth pattern (Fig. 5). Little difference in relative radial growth 

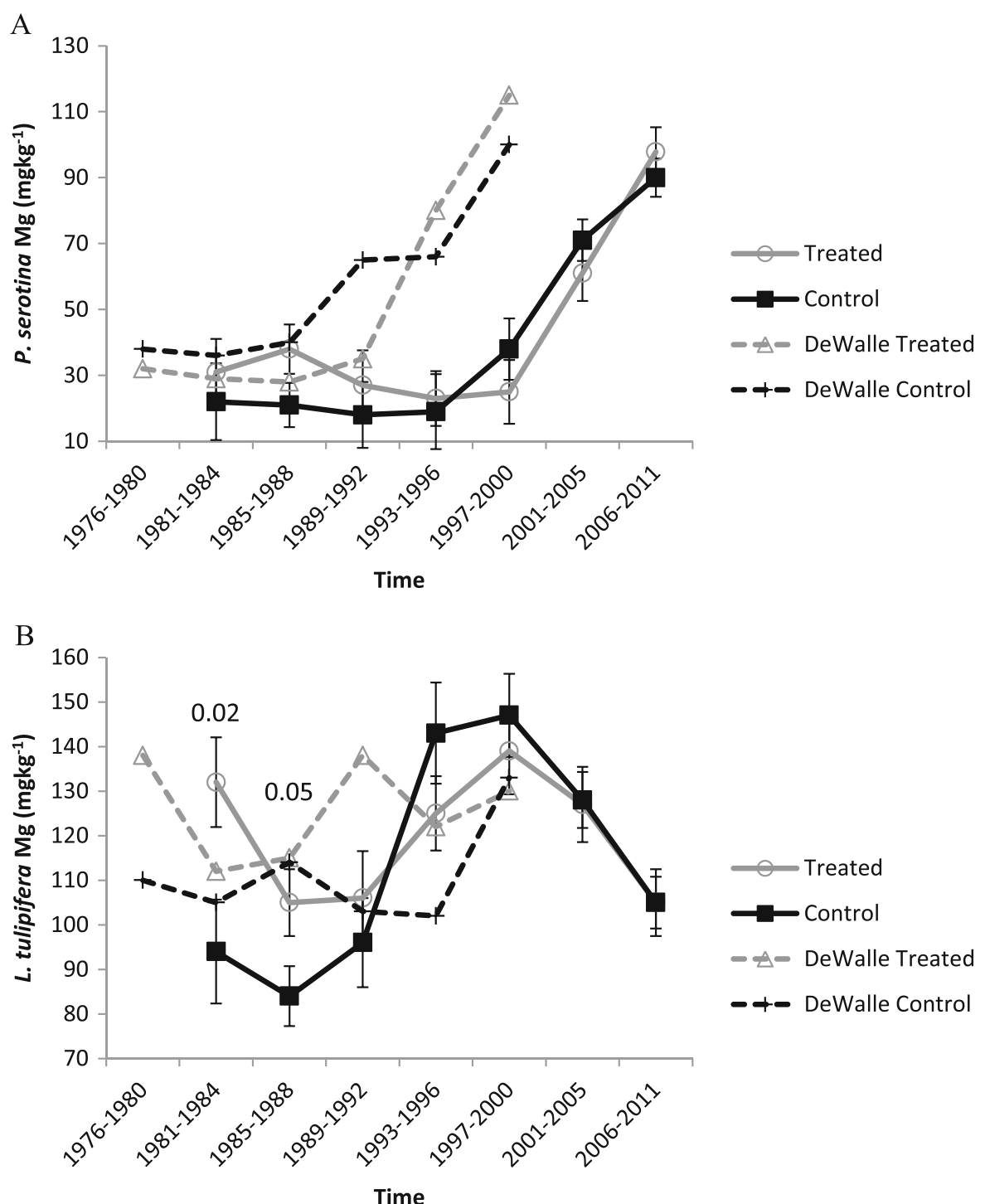

Fig. 2 P. serotina (a) and L. tulipifera (b) bolewood magnesium concentrations (mean $\pm 1 \mathrm{SE}$ ) on treated and control watersheds after 22 years of treatment and previous findings from DeWalle

was observed between the treated and control watersheds.

For field plot tree growth among all species, the basal area growth increase was greatest in the treated watershed from 1990 to 2003 ( $p \leq 0.08$; Fig. 6a). However, from 2003 to 2009, growth slightly decreased, but there was no difference between the two watersheds. For individual species, increased growth was observed for P. serotina from 1990 to 2003 and was greater in the treated watershed $(p<0.001$; Fig. $6 \mathrm{~b})$. The trend was reversed from 2003 to 2009, and growth was greater in et al. (2006). Treatment began in 1989. $P$ values depict differences between treatments for a given time period

the control watershed $(p=0.05)$. For $L$. tulipifera, positive growth was observed during the entire study period and was always greater in the control watershed $(p<0.05$; Fig. 6c).

\section{Discussion}

There were differences in tree-ring chemistry between the treated and control watersheds for both P. serotina and $L$. tulipifera, but the two species varied in their 

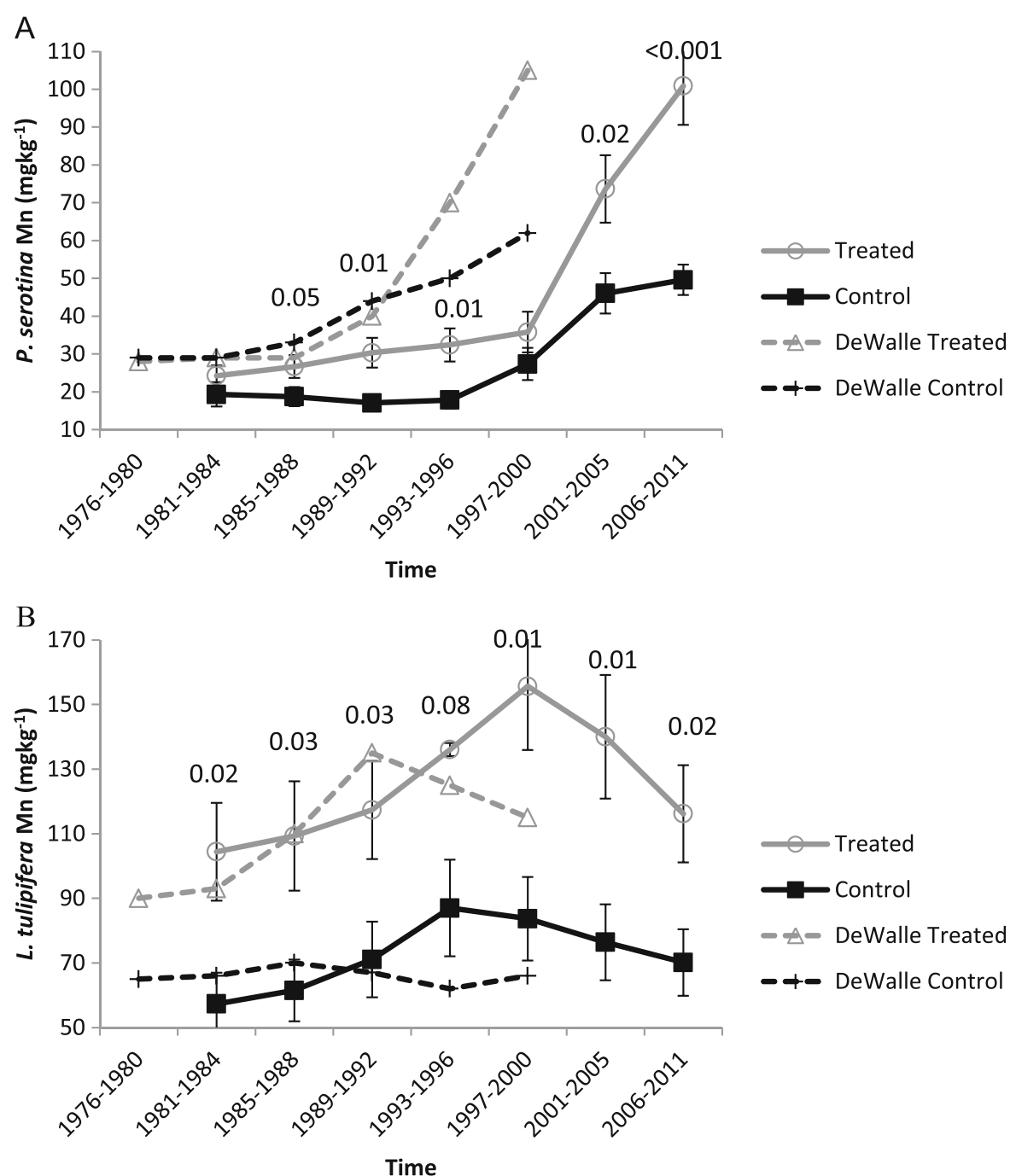

Fig. 3 P. serotina (a) and L. tulipifera (b) bolewood manganese concentrations (mean $\pm 1 \mathrm{SE}$ ) on treated and control watersheds after 22 years of treatment and previous findings from DeWalle

response. Changes in P. serotina bolewood element concentrations varied given the time period and element examined, but overall generally showed an increasing trend over time in both treated and control watersheds. By contrast, L. tulipifera elemental concentrations peaked around 2000 and then decreased in both the treated and control watersheds. Our results were similar to findings reported by DeWalle et al. (2006), but in our study, there was a shift in the concentration values and elemental concentrations. For similar time periods, our results were about $50-100 \mathrm{mg} \mathrm{kg}^{-1}$ lower for $\mathrm{Ca}$ and $10-50 \mathrm{mg} \mathrm{kg}^{-1}$ lower for $\mathrm{Mg}$ and $\mathrm{Mn}$ than DeWalle's findings for both species (Figs. 1-3). et al. (2006). Treatment began in 1989. $P$ values depict differences between treatments for a given time period

This shift in values may be attributed to radial translocation through xylem tissue via ray cells that redistributes elements in other portions of wood (Watmough 1999; Bilodeau-Gathier et al. 2008). Elements are potentially mobile within the xylem long after their uptake, and the mobility of water-soluble base cations $(\mathrm{Ca}, \mathrm{Mg}$, and $\mathrm{K}$ ) increases at higher soil acidity (BilodeauGauthier et al. 2011). McClenahen et al. (1989) reported $\mathrm{Mn}$ and $\mathrm{Ca}$ elements that are likely to move laterally. Another possibility to account for the shift is that the xylem may be operating as an ion exchange column and impeding movement up the bole so that samples from breast height may correspond to changes in soil 

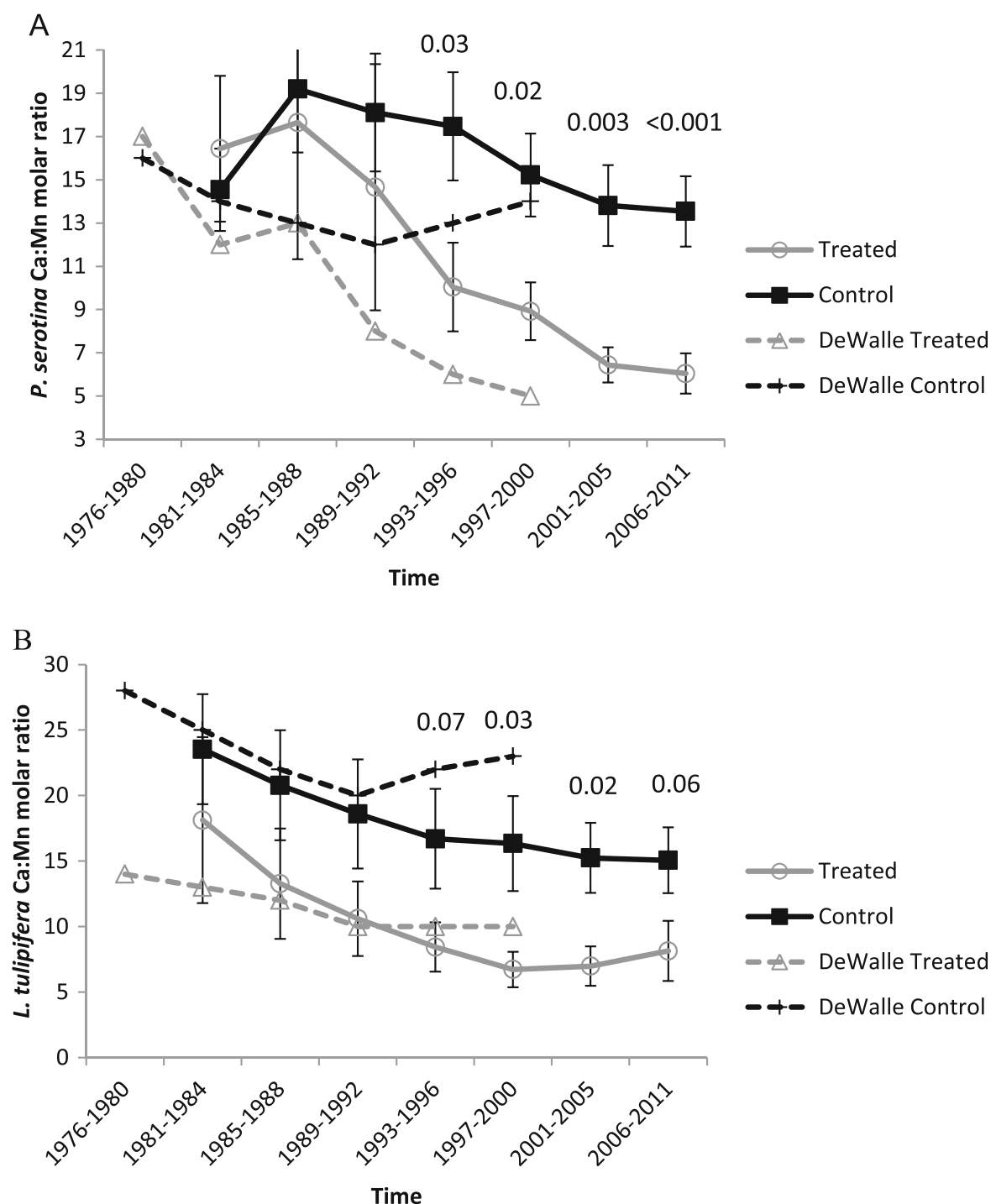

Fig. 4 P. serotina (a) and L. tulipifera (b) bolewood Ca/Mn molar ratios (mean $\pm 1 \mathrm{SE}$ ) on treated and control watersheds after 22 years of treatment and previous findings from DeWalle et al.
(2006). Treatment began in 1989. $P$ values depict differences between treatments for a given time period

control watersheds (Fig. 4). Similar patterns between the two watersheds may be attributed to chronic acidification of the area. Driscoll et al. (2001) reported that the majority of forest soils in the Northeastern USA are chronically acidic from decades of wet and dry acidic depositions. In our study soil, $\mathrm{pH}$ ranged from 3.9 to 4.3 in the treated and control watersheds, respectively (Jensen 2012), and the decreasing $\mathrm{Ca} / \mathrm{Mn}$ ratio indicates that $\mathrm{Ca}$ is still available in the soil, but at decreasing amounts compared to manganese. This could be decreasing $\mathrm{Ca}$, increasing $\mathrm{Mn}$, or both-likely it is due to 

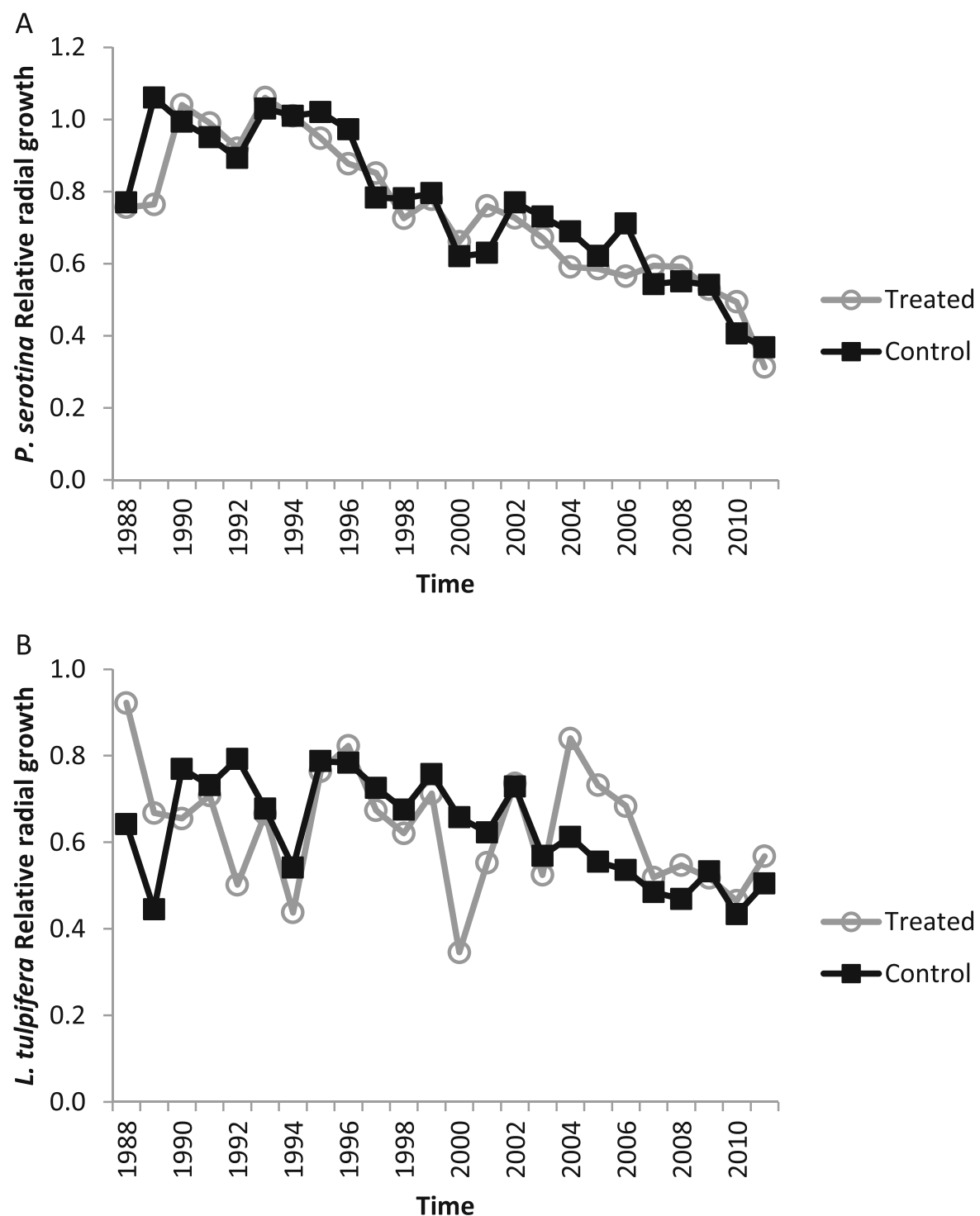

Fig. 5 Relative radial growth patterns for ten Prunus serotina (a) and ten Liriodendron tulipifera (b) trees on treated and control watersheds during acidification treatments which began in 1989

both-since base cation depletion is expected to occur simultaneously with increased Mn (and other metal) solubilization. Nevertheless, while both watersheds had decreasing ratios, the control watershed ratio was greater than the treated watershed for each period, indicating a negative treatment effect for both species.

Given the results in elemental bolewood concentrations and $\mathrm{Ca} / \mathrm{Mn}$, we expected to find distinct differences in the relative growth rates of the trees cored for elemental analysis. Multiple studies have observed a decrease in growth response due to acidification (Elias et al. 2009; Bilodeau-Gauthier et al. 2011). However, we found a steady decrease in relative growth over time for both species and in both watersheds. Therefore, decline in growth cannot be entirely attributed to treatment alone, and the decreasing tree growth patterns found on both watersheds may be attributed to much longerterm acidification due to atmospheric inputs of pollutants or stand age. Results from the 50 long-term permanent growth plots do indicate a different response to treatment. Prunus serotina growth rates were initially higher in the treated watershed. This species is well 

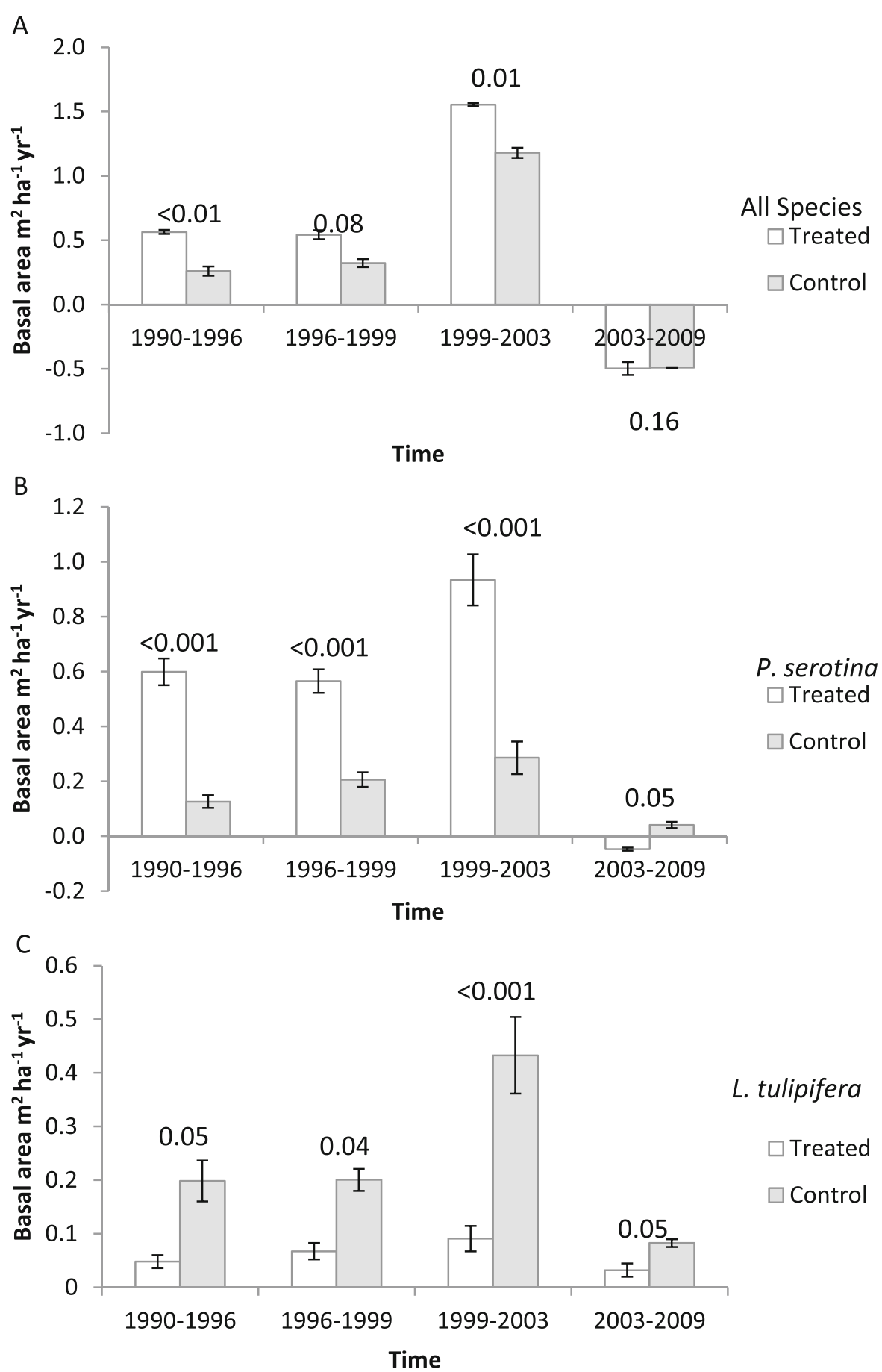

Fig. 6 The change in basal area (mean $\pm 1 \mathrm{SE}$ ) calculated from 25 growth plots on the treated and the control watersheds for all species (a), Prunus serotina (b), and Liriodendron tulipifera $(\mathbf{c})$. $P$ values depict differences between treatments for a given time period

known for its tolerance to and potential preference of very acidic soils, so its response is not surprising (Long et al. 2009). While the fertilization treatments may explain the greater growth rates of $P$. serotina from 1990 to 2003 (Fig. 6b), growth rates did decrease from 2003 to 2009, indicating that chronic acidification may 
have a negative long-term effect on species that normally perform well on acidic sites or that the trees are slowing in growth as the stand ages. Conversely, increased growth was not observed during any period on treated plots for L. tulipifera (Fig. 6c), indicating that the species may be more sensitive to acidification (Elias et al. 2009).

Although the link between tree-ring chemistry and tree growth was not as conclusive as expected, the depletion of Ca could have detrimental results for forest health. Calcium contributes to the structural stability of cell walls and membranes, and a reduction in $\mathrm{Ca}$ can affect wood formation and reduce a trees' ability to respond to wounding, cold shock, and defense against pests and pathogens (Holzmueller et al. 2007; Lautner and Fromm 2010). Both species had greater bolewood concentrations of $\mathrm{Mn}$ on the treated watershed compared to the control (Fig. 3). Excessive levels of manganese have been found to have toxic effects on Acer saccharum (Sharpe 2002) and could have similar effects on other species. In this study, A. saccharum stem density was similar in the overstory but less in the treated watershed understory.

\section{Conclusion}

After 22 years of study, the acidification treatment appears to show gradual impacts of acidification on wood chemistry and species-specific effects on growth. It is not clear though if the trees, either this cohort or future generations, will eventually show changes in growth from continued acidification. Further research is needed to analyze the recovery process if acidifying chemical inputs decline. The Clean Air Act of 1970 and further amendments in 1990 noticeably reduced air pollution in the Eastern USA (Greaver et al. 2012). Recovery from the impacts of acidification is very slow, but not impossible. For example, Tominaga et al. (2010) predicted a $90 \%$ probability of chemical recovery occurring between 2050 and 2100 at Hubbard Brook Experimental Forest in New Hampshire with stricter air pollution policies. Knowing the 1990 Clean Air Act Amendments will take additional time for biological recovery (Greaver et al. 2012); greater cooperation among scientists and policy makers must take place in order to make greater reductions in emissions and to come up with management solutions to mitigate these issues.
Acknowledgments This study was funded by the USFS Fernow Experimental Forest and the McIntire-Stennis Cooperative Forestry Program. Thanks to all who contributed to the study, including Dr. Charles Ruffner, Frederica Wood, Chris Cassidy, Robin Quinlivan, A\&L Laboratory, and the Pennsylvania State Analytical Lab.

\section{References}

Aber, J., McDowell, W., Nadelhoffer,K., Magill, A., Berntson, G., Kamakea, M., McNulty, S., Currie, W., Rustad, L., \& Fernandez, I. (1998). Nitrogen saturation in temperate forest ecosystems. BioScience, 48, 921-934.

Adams, M. B., DeWalle, D. R., \& Hom, J. L. (2006). The Fernow Watershed Acidification Study (pp. 17-279). Dordrecht, The Netherlands: Springer.

Adams, M. B., Kochenderfer, J. N., \& Edwards, P. J. (2007). The Fernow Watershed Acidification Study: ecosystem acidification, nitrogen saturation, and base cation leaching. Water, Air, and Soil Pollution, 7, 267-273.

Ågren, G. I. \& Bosatta, E. (1988). Nitrogen saturation of terrestrial ecosystems. Environmental Pollution, 54, 185-197.

Beauregard, S. L., Côté, B., \& Houle, D. (2009). Application of compositional nutrient diagnosis (CND) to the dendrochemistry of three hardwoods in three geological regions of southern Quebec. Dendrochronologia, 28, 23-36.

Bilodeau-Gauthier, S., Houle, D., Gagnon, C., Côté, B., \& Messier, C. (2008). Extractability of elements in sugar maple xylem along a gradient of soil acidity. Journal of Environmental Quality, 37, 871-879.

Bilodeau-Gauthier, S., Houle, D., Gagnon, C., Côté, B., \& Messier, C. (2011). Assessment of sugar maple tree growth in relation to the partitioning of elements in xylem along a soil acidity gradient. Forest Ecology and Management, 261, 95-104.

DeForest, J. L., \& McCarthy, B. C. (2011). Diminished soil quality in an old-growth, mixed mesophytic forest following chronic acid deposition. Northeastern Naturalist, 18, 177-184.

DeWalle, D. R., Tepp, J. S., Swistock, B. R., Sharpe, W. E., \& Edwards, P. J. (1999). Tree-ring cation response to experimental watershed acidification in West Virginia and Maine. Journal of Environmental Quality, 28, 299-309.

DeWalle, D. R., Kochenderfer, J. N., Adams, M. B., Miller, G. W., Gilliam, F. S., Wood, F., et al. (2006). Vegetation and acidification, Chapter 5. In M. B. Adams, D. R. DeWalle, \& J. L. Hom (Eds.), The Fernow Watershed Acidification Study (pp. 137-188). Dordrecht, The Netherlands: Springer.

Driscoll, C. T., Lawrence, G. B., Bulger, A. J., Butler, T. J., Cronan, C. S., Eagar, C., et al. (2001). Acidic deposition in the Northeastern United States: sources and inputs, ecosystem effects, and management strategies. Bio Science, 51, 180-198.

Edwards, P. J., Kochenderfer, J. N., Coble, D. W., \& Adams, M. B. (2002). Soil leachate responses during 10 years of induced whole-watershed acidification. Water, Air, and Soil Pollution, 140, 99-118. 
Elias, P. E., Burger, J. A., \& Adams, M. B. (2009). Acid deposition effects on forest composition and growth on the Monongahela National Forest, West Virginia. Forest Ecology and Management, 258, 2175-2182.

Greaver, T. L., Sullivan, T. J., Herrick, J. D., Barber, M. C., Baron, J. S., Cosby, B. J., et al. (2012). Ecological effects of nitrogen and sulfur air pollution in the US: what do we know? Frontiers in Ecology and the Environment, 10, 365-372.

Holzmueller, E. J., Jose, S., \& Jenkins, M. A. (2007). Influence of calcium, potassium, and magnesium on Cornus florida L. density and resistance to dogwood anthracnose. Plant and Soil, 290, 189-199.

Huang, C.-Y. L., \& Shulte, E. E. (1985). Digestion of plant tissue for analysis by ICP emission spectroscopy. Community Soil Science Plant Analysis, 16, 943-958.

Jensen, N.K. (2012). Tree-ring chemistry and growth response to experimental watershed acidification. MS Thesis. Southern Illinois University.

Kochenderfer, J. N. (2006). Fernow and the Appalachian Hardwood Region, Chapter 2. In M. B. Adams, D. R. DeWalle, \& J. L. Hom (Eds.), The Fernow Watershed Acidification Study (pp. 17-39). Dordrecht, The Netherlands: Springer.

Lautner, S., \& Fromm, J. (2010). Calcium-dependent physiological processes in trees. Plant Biology, 12, 268-274.

Long, R. P., Horsley, S. B., Hallett, R. A., \& Bailey, S. W. (2009). Sugar maple growth in relation to nutrition and stress in the northeastern United States. Ecological Applications, 19, 1454-1466.

Lu, X., Gilliam, F. S., Yu, G., Li, L., Mao, Q., Chen, H., et al. (2013). Long-term nitrogen addition decreases carbon leaching in nitrogen-rich forest ecosystems. Biogeosciences Discussions, 10, 1451-1481.

McClenahen, J. R., Vimmerstedt, J. P., \& Scherzer, A. J. (1989). Elemental concentrations in tree rings by PIXE: statistical variability, mobility, and effects of altered soil chemistry. Canadian Journal of Forest Research, 19, 880-888.

Schuler, T. M. (2004). Fifty years of partial harvesting in a mixed mesophytic forest: composition and productivity. Canadian Journal of Forest Research, 34, 985-997.

Sharpe, W. E. (2002). Acid deposition explains sugar maple decline in the east. Bioscience, 52, 4-5.

Stoddard, J. L. (1994). Long-term changes in watershed retention of nitrogen: its causes and aquatic consequences. Advances in Chemistry, 237, 223-284.

Talhelm, A. F., Burton, A. J., Pregitzer, K. S., \& Campione, M. A. (2013). Chronic nitrogen deposition reduces the abundance of dominant forest understory and groundcover species. Forest Ecology and Management, 293, 39-48.

Tominaga, K., J. Aherne, S.A. Watmough, M. Alveteg, B.J. Cosby, C.T. Driscoll, M. Posch, and A. Pourmokhtarian. (2010). Predicting acidification recovery at the Hubbard Brook Experimental Forest, New Hampshire: evaluation of four models. Environmental Science and Technology, 44.

Watmough, S. A. (1997). An evaluation of the use of dendrochemical analyses in environmental monitoring. Environmental Review, 5, 181-201.

Watmough, S. A. (1999). Monitoring historical changes in soil and atmospheric trace metal levels by dendrochemical analysis. Environmental Pollution, 106, 391-403. 